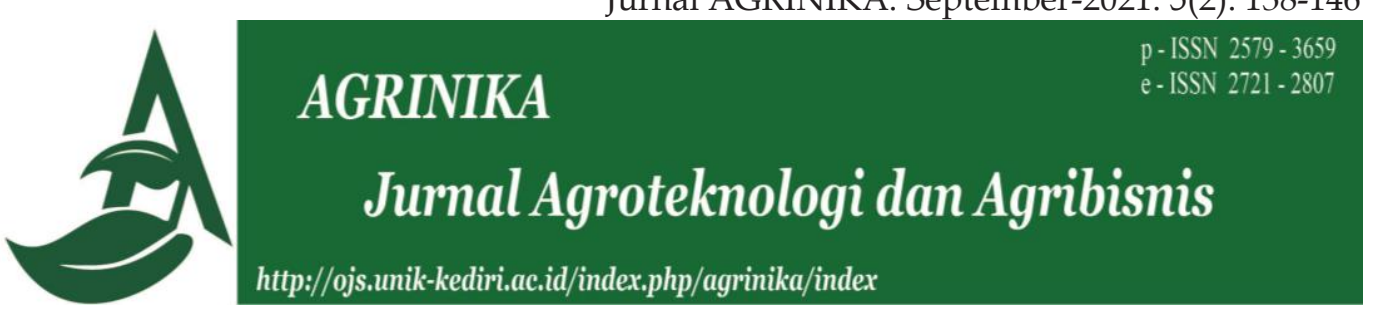

\title{
Sikap dan Partisipasi Petani dalam Program Pelatihan Agribisnis Kedelai di Kabupaten Grobogan
}

\author{
Agus Subhan Prasetyo ${ }^{1 *}$,Siwi Gayatri ${ }^{1}$, Sriroso Satmoko ${ }^{1}$ \\ ${ }^{1}$ Program Studi Agribisnis, Departemen Pertanian, Fakultas Peternakan dan Pertanian, \\ Universitas Diponegoro, Semarang, Indonesia \\ *Korespondensi: setyo.subhan@live.undip.ac.id
}

Diterima 03 Agustus 2021/ Direvisi 09 September 2021/ Disetujui 22 September 2021

\begin{abstract}
ABSTRAK
Kesejahteraan petani merupakan titik sentral pembangunan pertanian. Namun pada kenyataannya petani masih memiliki banyak masalah. Salah satu solusi dari pemerintah adalah melalui program pemberdayaan petani. Hal ini bertujuan untuk meningkatkan pengetahuan, sikap, dan keterampilan para petani sehingga dapat mengembangkan usaha tani yang lebih produktif. Untuk mendukung program tersebut diperlukan sikap dan partisipasi yang tinggi dari petani. Oleh karena itu, penelitian ini dilakukan dengan tujuan untuk menganalisis sikap dan partisipasi petani dalam program pelatihan agribisnis kedelai di Kabupaten Grobogan. Penelitian ini menggunakan metode studi kasus. Teknik penentuan responden menggunakan metode sensus. Responden penelitian ini adalah 109 petani yang mengikuti program pelatihan agribisnis kedelai. Pengumpulan data dilakukan dengan menggunakan kuesioner, wawancara, observasi dan studi kepustakaan. Analisis deskriptif dan skala likert digunakan untuk menganalisis data. Hasil penelitian menunjukkan bahwa sikap petani terhadap program pelatihan agribisnis kedelai berada pada kategori baik. Sikap petani dalam program pelatihan agribisnis kedelai dilihat dari tiga indikator, 1) kognitif, 2) afektif, dan 3) psikomotorik. Selain itu, partisipasi petani dalam program pelatihan agribisnis kedelai sudah maksimal dan tergolong dalam kategori tinggi. Kondisi ini menujukkan bahwa petani aktif dalam pelaksanaan program pelatihan agribisnis kedelai. Keaktifan petani bukan hanya bertanya melainkan aktif memberikan pendapat berdasarkan pengalaman yang dimiliki. Sehingga menjadikan petani mampu memahami dan menerapkan materi yang telah diberikan oleh fasilitator.
\end{abstract}

Kata kunci : Agribisnis kedelai; Partispasi; Pelatihan; Sikap

\begin{abstract}
Farmers' welfare is the central point of agricultural development. Nevertheless, farmers still have many problems. One of the solutions from the government is through farmer empowerment programs. It aims to increase the knowledge, attitudes, and skills of farmers to develop more productive farming. Proper farmers' attitudes and participation in supporting the program are required. Therefore, this research was conducted to analyze the attitude and participation of farmers in the soybean agribusiness training program in the Grobogan Regency. The research used a case study method. The technique of determining respondents used the census method. Respondents to the research were 109 farmers who participated in the soybean agribusiness training program. The data was collected by using a questionnaire, interview, observation, and literature study. Descriptive analysis and the Likert scale were used to analyze the data. Overall, the research results showed that the attitude of farmers to the soybean agribusiness training program is in a "good" category. The attitude of farmers in the soybean agribusiness
\end{abstract}


training program was seen from three indicators, 1) cognitive, 2) affective, and 3) psychomotor. In addition, the participation of farmers in soybean agribusiness training programs has been maximized and is classified in the high category. This condition showed that farmers were active in the implementation of soybean agribusiness training programs. Farmers were not only active in asking questions but actively giving opinions based on their experiences. So that farmers were able to understand and applied the material that the facilitator had given.

Keywords: Attitude; Participation; Soybean agribusiness; Training

\section{PENDAHULUAN}

Fokus pemerintah Indonesia dalam upaya peningkatan perekonomian dan kesejahteraan masyarakat dilakukan melalui pembangunan pertanian. Langkah awal yang ditempuh oleh pemerintah Indonesia dalam mencapai terwujudnya pembangunan pertanian dengan dilakukannya pendekatan kelompok tani. Pendekatan kelompok tani dipilih oleh pemerintah karena kelompok tani merupakan wadah bagi petani untuk saling bertukar informasi, pengetahuan, dan pengalaman, sehingga mampu menciptakan perubahan perilaku bagi petani (Prasetyo et al., 2019). Selain itu kelompok tani menjadi jembatan bagi pemerintah dalam memberikan bantuan maupun pelaksanaan program-program pembangunan yang disusun untuk mencapai kesejahteraan petani.

Salah satu program yang dilakukan oleh pemerintah yaitu penguatan pengetahuan petani dengan melakukan kegiatan pelatihan. Seperti halnya yang dilakukan oleh pemerintah Kabupaten Grobogan yang memberikan pelatihan agribisnis kedelai dengan tujuan meningkatkan dan menguatkan pengetahuan petani akan usaha agribisnis kedelai. Keberhasilan dari pelaksanaan program yang dilakukan ditentukan dari sikap petani. Menurut Gerungan (2014) sikap merupakan pandangan atau perasaan disertai dengan kecenderungan untuk bertindak. Sikap terdiri dari komponen kognitif, afektif dan psikomotorik. Sikap yang dimaksud dalam penelitian ini sikap petani terhadap program pelatihan agribisnis kedelai. Sikap petani dilihat dari aspek kognitif yang mencakup: 1) pengetahuan mengenai kegiatan program pelatihan agribisnis kedelai, 2) pengetahuan mengenai nilai tambah dari pengelolahan kedelai, dan 3) pengetahuan indentifikasi masalah dalam agribisnis kedelai. Aspek afektif mencakup: 1) keterbukaan menerima pengetahuan baru, dan 2) respon mengenai program pelatihan agribisnis kedelai. Aspek psikomotorik mencakup: 1) terampil dalam mengaplikasikan hasil program pelatihan agribisnis kedelai, 2) kreatif dalam mengembangkan pengolahan kedelai, dan 3) terampil dalam berkomunikasi

Keberhasilan program bukan hanya ditentukan dari sikap melainkan juga partisipasi dari petani. Musabbikhin et al., (2020) menyebutkan bahwa partisipasi petani merupakan tingkat kemampuan dan kemauan petani dalam mengikuti pelaksanaan program dengan memberikan ide, pemikiran, waktu, dan materi untuk membantu tercapai tujuan dari pelaksanaan program tersebut. Partisipasi petani dapat berupa keikutsertaan dalam perencanaan, pelaksanaan, dan evaluasi dari suatu kegiatan. Penelitian ini bertujuan menganalisis sikap dan partisipasi petani dalam program pelatihan agribisnis kedelai di Kabupaten Grobogan. 


\section{BAHAN DAN METODE}

Penelitian ini dilakukan di Kabupaten Grobogan. Penentuan lokasi dilakukan secara purposive dengan pertimbangan bahwa petani yang ada di Kabupaten Grobogan mayoritas sebagai petani kedelai dan petani yang mengikuti program agribisnis kedelai dari Dinas Pertanian Kabupaten Grobogan. Metode penelitian yang dilakukan dalam penelitian ini menggunakan metode studi kasus. Penentuan responden dalam penelitian ini menggunakan sensus. Responden yang digunakan adalah seluruh perserta program yang berjumlah 109. Teknik yang digunakan dalam pengumpulan data yaitu wawancara, observasi, studi literatur. dan kuesioner.

Indikator dalam kuesioner menggunakan lima point skala likert. Indikator sikap dalam penelitian ini mencangkup 3 aspek yaitu kognitif, afektif dan psikomotorik. Sedangkan, indikator pengukuran partisipasi yaitu 1) tahap perencanaan, 2) tahap pelaksanaan dan 3) tahap monitoring dan evaluasi.. Metode analisis data yang digunakan adalah analisis deskirptif.

Menurut Sugiyono (2007) analisis deskriptif merupakan analisis yang digunakan untuk mendeskripsikan data yang telah terkumpul sesuai dengan fakta yang ada di lapangan. Data yang diperoleh dari hasil penelitian terdiri dari sikap dan partisipasi petani dalam pelaksanaan Program Pelatihan Agribisnis Kedelai yang dideskripsikan sesuai dengan fakta yang telah diperoleh

\section{HASIL DAN PEMBAHASAN}

Sikap Petani Terhadap Program Pelatihan Agribisnis Kedelai
Tujuan dari pembangunan pertanian di Indonesia adalah kesejahteraan petani. Kesejahteraan petani dapat tercapai jika petani memiliki keberdayaan dalam melakukan kegiatan usahatani (Hermanto \& Swastika, 2011). Guna mencapai keberdayaan tersebut perlu adanya program pemberdayaan petani melalui kelompok tani. Program pemberdayaan dapat dilakukan dengan memberikan pelatihan kepada kelompok tani. Salah satu bentuk program pemberdayaan petani yaitu Program Pelatihan Agribisnis Kedelai di Kabupaten Grobogan. Program ini dilakukan bertujuan untuk merubah perilaku petani dan meningkatkan nilai jual dari kedelai. Keberhasilan program tentunya ditentukan pula dari sikap petani terhadap program tersebut. Sebagaimana yang dikatakan oleh Sumekar et al., (2021) bahwa keberhasilan program bergantung pada sikap yang baik dari petani, hal inilah yang menjadikan keberhasilan dari kegiatan program lebih mudah tercapai. Berdasarkan hal tersebut penelitian ini dilakukan untuk menganilisis sikap petani. Analisis sikap petani dalam penelitian ini diukur berdadsarkan tiga aspek yaitu kognitif, afektif dan psikomotorik. Hasil penelitian mengenai sikap petani terhadap program pelatihan agribisnis kedelai secara rinci diuaraikan sebagai berikut:

\section{Aspek Kognitif}

Aspek kognitif dalam penelitian ini diukur berdasarkan pengetahuan mengenai kegiatan program pelatihan agribisnis kedelai, Pengetahuan mengenai nilai tambah dari pengelolahan kedelai, dan Pengetahuan 
indentifikasi masalah dalam agribisnis kedelai. Hasil penelitian menujukkan bahwa aspek kognitif petani berada pada kategori baik dengan rata-rata total 12,11 atau $80,73 \%$ dari total skor maksimum 15. Pengukuran Indikator secara rinci disajikan pada Tabel 1.

Tabel 1. Skor kognitif petani dalam program pelatihan agribisnis Kedelai

\begin{tabular}{|c|c|c|c|c|c|}
\hline No & Indikator & $\begin{array}{c}\text { Skor } \\
\text { Maksimal }\end{array}$ & $\begin{array}{c}\text { Skor } \\
\text { yang } \\
\text { dicapai }\end{array}$ & $\begin{array}{c}\text { Persentase } \\
(\%)\end{array}$ & Katagori \\
\hline 1 & $\begin{array}{l}\text { Pengetahuan mengenai } \\
\text { kegiatan program pelatihan } \\
\text { agribisnis kedelai }\end{array}$ & 5 & 4,26 & 85,14 & Baik \\
\hline 2 & $\begin{array}{l}\text { Pengetahuan mengenai } \\
\text { nilai tambah dari } \\
\text { pengelolahan kedelai }\end{array}$ & 5 & 3,76 & 75,23 & Sedang \\
\hline 3 & $\begin{array}{l}\text { Pengetahuan indentifikasi } \\
\text { masalah dalam agribisnis } \\
\text { kedelai. }\end{array}$ & 5 & 4,09 & 81,83 & Baik \\
\hline
\end{tabular}

Sumber: Data primer diolah

Berdasarkan Tabel 1 dapat dilihat bahwa indikator pengetahuan mengenai kegiatan program pelatihan agribisnis kedelai memiliki nilai $85,14 \%$. Indikator ini termasuk dalam dalam kategori baik yang berarti bahwa petani telah mengetahui adanya kegiatan program pelatihan, dan mengetahui mengenai hak dan kewajiban yang harus dilakukan untuk mengikuti program tersebut. Hak yang harus diterima oleh petani adalah materi mengenai agribisnis kedelai, bagaimana cara menambah nilai tambah dari kedelai, pelatihan dan pendampingan pengolahan kedelai, serta informasi mengenai informasi pemasaran hasil pengolahan. Sedangkan, kewajiban yang harus dilakukan oleh petani yaitu mengikuti dan berpartisipasi secara aktif dalam pelaksanaan program pelatihan tersebut.

Indikator pengetahuan mengenai nilai tambah dari pengolahan kedelai termasuk dalam kategori sedang dengan nilai presentase $75,23 \%$. Hal ini menujukkan bahwa petani belum begitu mengetahui nilai tambah dari pengolahan kedelai. Petani memahami proses pengolahan kedelai menjadi berbagai makanan hanya melalui proses yang sederhana, dan peralatan yang digunakan cukup dengan alat-alat yang biasa dipakai di rumah tangga.

Nilai petani dalam indikator pengetahuan indentifikasi masalah dalam agribisnis kedelai yaitu sebesar $81,83 \%$, sehingga indikator ini masuk dalam kategori baik. Kondisi ini mengartikan bahwa petani masih mampu mengidentifikasi masalah yang ada dalam agribisnis kedelai. Dari hasil wawancara petani menyebutkan bahwa masalah yang ada yaitu 1) proses pengolahan kedelai masih menggunakan alat yang sederhana, 2) keterbatasan modal, dan 3) pemasaran yang masih mencangkup daerah-daerah sekitar (terbatas).

\section{Aspek Afektif}

Indikator afektif dalam penelitian di analisis dengan tiga indokator yaitu keterbukaan menerima pengetahuan baru, respon mengenai program 
Agus Subhan Prasetyo, Sikap dan Partisipasi ...

pelatihan agribisnis kedelai, dan komitmen dan tanggung jawab dalam pelaksanaan program. Hasil penelitian mengenai aspek afektif secara umum

termasuk dalam kategori baik dengan nilai sebesar $84,71 \%$. Pengukuran indikator secara detail dapat dilihat pada Tabel 2.

Tabel 2. Skor aspel afektif petani dalam program pelatihan agribisnis Kedelai

\begin{tabular}{clcccc}
\hline No & Indikator & $\begin{array}{c}\text { Skor } \\
\text { Maksimal }\end{array}$ & $\begin{array}{c}\text { Skor } \\
\text { yang } \\
\text { dicapai }\end{array}$ & $\begin{array}{c}\text { Persentase } \\
(\%)\end{array}$ & Katagori \\
\hline 1 & $\begin{array}{l}\text { Keterbukaan menerima } \\
\text { pengetahuan baru }\end{array}$ & 5 & 4,27 & 85,32 & $\begin{array}{c}\text { Sangat } \\
\text { Baik } \\
\text { Baik }\end{array}$ \\
$\begin{array}{l}\text { Respon mengenai program } \\
\text { pelatihan agribisnis kedelai }\end{array}$ & 5 & 4,20 & 84,04 & Baik \\
\hline & 10 & 8,47 & 84,71 & \\
\hline
\end{tabular}

Sumber: Data primer diolah

Dari tabel 2 dapat diketahui bahwa aspek afektif dengan indikator keterbukaan menerima pengetahuan baru memiliki nilai $85,32 \%$ dengan katagori sangat baik. $\mathrm{Hal}$ ini menunjukkan bahwa petani yang ada di Kabupaten Grobogan terbuka akan pengetahuan baru. Menurut petani di Kabupaten Grobogan pengetahuanpengetahuan lain seharusnya diketahui oleh petani untuk bisa memperbaiki usahatani yang dijalankan agar menjadi lebih baik lagi. Senada dengan pendapat Agustin (2019) dalam penelitiannya menyebutkan bahwasannya seharusnya petani memiliki pengetahuan yang lebih baik, karena setiap petani memiliki cara pengolahan dan hasil produksinya berbeda-beda.

Tabel 2 juga menunjukkan bahwa indikator respon mengenai program pelatihan agribisnis kedelai termasuk dalam kategori baik dengan nilai $84,04 \%$. Hal ini berarti petani di Kabupaten Grobogan memiliki respon yang baik. Respon menurut Wawan dan Dewi (2010) merupakan bentuk reaksi yang dinyatakan sebagai sikap itu timbulnya didasari oleh proses evaluasi dalam diri individu yang memberi kesimpulan terhadap stimulus dalam bentuk nilai baik - buruk, positif - negatif, menyenangkan - tidak menyenangkan. Dari hasil penelitian terlihat bahwa petani yang mengiktui program pelatihan agribisnis kedelai merasa senang dengan adanya kegiatan tersebut. Petani juga mengikuti setiap arahan yang diberikan oleh fasilitator. Petani merasa dengan adanya kegiatan ini mendapatkan pengetahuan baru yang bermanfaat sehingga dapat meingkatkan usahatani yang dilakukan bisa menjadi lebih baik.

\section{Aspek Psikomotorik}

$$
\text { Walgito (1999) menjelaskan }
$$

bahwa sikap dapat dilihat dari komponen kognitif, afektif dan psikomotorik. Dalam bidang pertanian sikap petani dapat dilihat dari psikomotorik yang dimiliki oleh petani. Indikator psikomotik dalam penelitian ini mencangkup tiga hal yaitu terampil dalam mengaplikasikan hasil program pelatihan agribisnis kedelai, kreatif dalam mengembangkan pengolahan kedelai, dan terampil dalam berkomunikasi. Hasil penelitian mengenai aspek psikomotorik diketahui memiliki nilai $81,77 \%$ dengan kategori 
Agus Subhan Prasetyo, Sikap dan Partisipasi ...

baik, secara rinci dapat dilihat pada

tabel 3

Tabel 3. Skor aspek psikomotorik petani dalam program pelatihan agribisnis Kedelai

\begin{tabular}{clcccc}
\hline No & \multicolumn{1}{c}{ Indikator } & $\begin{array}{c}\text { Skor } \\
\text { Maksimal }\end{array}$ & $\begin{array}{c}\text { Skor } \\
\text { yang } \\
\text { dicapai }\end{array}$ & $\begin{array}{c}\text { Persentase } \\
(\%)\end{array}$ & Katagori \\
\hline 1 & 5 & 4,08 & 81,65 & Baik \\
& $\begin{array}{l}\text { Terampil dalam } \\
\text { mengaplikasikan hasil } \\
\text { program pelatihan agribisnis } \\
\text { kedelai } \\
\text { Kreatif dalam } \\
\text { mengembangkan } \\
\text { pengolahan kedelai }\end{array}$ & 5 & 4,06 & 81,28 & Baik \\
3 & $\begin{array}{l}\text { Terampil dalam } \\
\text { berkomunikasi }\end{array}$ & 5 & 4,12 & 82,39 & Baik \\
\hline$\quad$ Jumlah & 15 & 12,27 & 81,77 & Baik \\
\hline
\end{tabular}

Sumber: Data primer diolah

Berdasarkan tabel 3 dapat diketahui bahwa indikator terampil dalam mengaplikasikan hasil program pelatihan agribisnis kedelai termasuk kategori baik dengan nilai sebesar $81,65 \%$. Kondisi ini menujukkan bahwa petani terampil dalam mempratikkan secara mandiri hasil arahan yang diapat dari kegiatan pelatihan. Petani mampu mengaplikasikan materi yang didapat dari kegiatan pelatihan agribisnis kedelai.

Indikator kreatif dalam mengembangkan pengolahan kedelai pertama keterampilan budidaya organik termasuk dalam kategori baik dengan nilai sebesar $81,28 \%$. Kreativitas dalam penelitian ini yaitu kemampuan petani dalam mengembangakan ilmu-ilmu dalam agribisnis kedelai. Kemampuan yang dimaksud meliputi penambahan nilai tambah dari pengolahan pasca panen kedelai. Kondisi lapang menunjukkan bahwa petani mampu mengikuti kegiatan pelatihan yang dilakukan sehingga petani mampu untuk mengaplikasikan ilmu yang didapatkan. Sehingga petani mampu melakukan pengembangan usaha melalui pengolahan hasil panen kedelai.

Tabel 3 juga menjukkan bahwa indikator terampil dalam berkomunikasi memilikii nilai sebesar $82,39 \%$ dengan kategori baik. Hal ini dapat dilihat bahawa petani memiliki ketrampilan komunikasi yang baik. Komunikasi petani terlihat dari bagaimana petani aktif memberikan pendapat dan bertanya dalam kegiatan pelatihan agribinis kedelai. Selain itu, petani juga aktif berkomunikasi dengan petani yang lainnya untuk bertukar pengalaman mengenai usahatani yang dijalankan, dan saling bertukar informasi mengenai agrbisnis kedelai. Hal ini sejalan dengan penelitian yang dilakukan oleh Prasetyo et al., (2019) bahwa komunikasi yang baik dalam kelompok tani adalah komunikasi yang terjadi antar petani dan komunikasi petani dengan fasilitator. Komunikasi yang terjadi ini akan mampu meningkatkan pengetahuan informasi dan dan menambah pengalaman petani, sehingga mampu menjadikan usatani terutamanya agribisnis kedelai menjadi lebih baik. 
Partisipasi Petani Terhadap Program Pelatihan Agribisnis Kedelai

Partisipasi merupakan
keterlibatan petani dalam setiap program yang bertujuan menjadikan petani lebih baik di masa depan dalam melanjalankan usahataninya (Mardikanto, 2010). Partisipasi dalam penelitian ini dilihat dari aktivitas atau keterlibatan langsung petani. Aktivitas atau keterlibatan langsung ini terbagi menjadi tiga indikator yaitu tahap perencanaan, tahap pelaksanaan dan tahap monitoring dan evaluasi. Hasil penlitian menujukkan bahwa partisipasi petani dalam Program Pelatihan Agribisnis Kedelai termasuk kategori tinggi dengan nilai sebesar 12,24 atau sebesar $81,59 \%$ dari skor maksimal 15 . Secara rinci dapat dilihat pada tabel 4.

Tabel 4. Partisipasi petani dalam program pelatihan agribisnis Kedelai

\begin{tabular}{clcccc}
\hline No & Indikator & $\begin{array}{c}\text { Skor } \\
\text { Maksimal }\end{array}$ & $\begin{array}{c}\text { Skor } \\
\text { yang } \\
\text { dicapai }\end{array}$ & $\begin{array}{c}\text { Persentase } \\
(\%)\end{array}$ & Katagori \\
\hline 1 & Tahap Perencanaan & 5 & 3,98 & 79,63 & Sedang \\
2 & Tahap Pelaksanaan & 5 & 4,17 & 83,30 & Tinggi \\
3 & $\begin{array}{l}\text { Tahap Monitoring dan } \\
\text { Evaluasi }\end{array}$ & 5 & 4,09 & 81,83 & Tinggi \\
\hline & Jumlah & 15 & 12,24 & 81,59 & Tinggi \\
\hline
\end{tabular}

Sumber: Data primer diolah

Tabel 4 menujukkan bahwa partisipasi petani pada tahap perencanaan mendapatkan skor presentase sebesar $79,73 \%$ termasuk dalam kategori sedang. Hal mengartikan bahwa pada tahapan perencanaan tidak semua petani hadir atau terlibat dalam kegiatan perencanaan program pelatihan. Petani yang hadir dalam kegiatan perencanaan program hanya di hadiri oleh perwakilan pengurus kelompok tani yang ada di kabupaten Grobogan. Petani anggota hanya menunggu keputusan dan mengikuti program yang sudah di tentukan. Oleh karena itu, pada tahap perencanaan partisipasi petani dalam Program Pelatihan Agribisnis Kedelai belum maksimal.

Indikator pelaksanan dari hasil penelitian diperoleh hasil skor sebesar $83,30 \%$ termasuk dalam kategori tinggi. Kondisi ini menujukkan bahwa petani yang hadir mampu berpartisipasi aktif dalam kegiatan Program Pelatihan Agribisnis Kedelai. Partisipasi aktif yang dimaksud yaitu dimana petani yang hadir turut aktif dalam setiap kegiatan yang diberikan oleh fasilitator. Petani mampu mengikuti kegiatan setiap tahapan dalam kegiatan pelatihan yang diberikan. Hal ini sejalan dengan yang diutarakan oleh Untarti dan Kusuma (2018) bahwa partisipasi aktif adalah keterlibatan secara aktif baik secara fisik, mental maupun emosi dalam setiap kegiatan yang dilakukan.

Berdasarkan tabel 4 menujukkan bahwa indikator tahap monitoring dan evaluasi termasuk kategori tinggi dengan nilai presentase sebesar $81,83 \%$. Tahap ini memperlihatkan bahwa keikutsertaan petani pada pengontrolan dan evaluasi kegiatan pelatihan terhadap Program Pelatihan Agribisnis Kedelai tergolong maksimal. 
Maksimalnya partisipasi petani dalam tahap ini telihat petani banyak terlibat bukan hanya pengurus dan fasilitator dari kegiatan program pelatihan tersebut. Petani juga aktif dalam hal memberikan kritik dan masukan kepada fasilitator, terhadap kegiatan yang telah berlangsung sehingga kegiatan pelatihan berikutnya dapat berjalan lebih baik lagi.

\section{KESIMPULAN}

Berdasarkan hasil dan pembahasan dapat disimpulkan bahwa Sikap petani dalam Program Pelatihan Agribisnis kedelai yang dilihat dari inidikator kognitif, afektif dan psikmotorik termasuk dalam kategori baik. Ketiga aspek tersebut secara berurutan memiliki persentase skor $80,73 \%$, $84,70 \%$, dan $81,77 \%$. Hal ini menunjukkan bahwa petani mampu memahami dan menerapkan materi yang telah diberikan oleh fasilitator dalam kegiatan Program Pelatihan Agribisnis Kedelai. Selain itu partisipasi petani dalam Program Pelatihan Agribisnis Kedelai termasuk kategori tinggi dengan skor presentasi sebesar $81,59 \%$. Skor ini menunjukkan bahwa petani aktif dalam kegiatan program tersebut. Keaktifan petani bukan hanya bertanya melainkan juga aktif dalam memberikan pendapat.

\section{UCAPAN TERIMAKASIH}

Terimakasih peneliti ucapkan kepada Fakultas Peternakan dan Pertanian Universitas Diponegoro yang telah memberikan dana penelitian kepda peniti berseta tim. Terima kasih juga kepada Dinas Pertanian dan Petani Kabupaten Grobogan yang telah membersamai dalam penelitian

\section{DAFTAR PUSTAKA}

Agustin, L.F. ( 2019). Knowledge Dan Persuasion dalam Strategi Tim Superagro untuk Menciptakan Petani Kosmopolitan. Commercium, 1(2) 123-126.

Gerungan, 2004. Psikologi Sosial. Bandung: Refika Aditama.

Hermanto \& Swastika D. K. S.. 2011. Penguatan Kelompok Tani: Langkah Awal Peningkatan Kesejahteraan Petani. J. Analisis Kebijakan Pertanian. 9(4):371390.

Mardikato, T. 2010. Komunikasi Pembangunan. Surakarta: UPT Penertiban dan Percetakan UNS (UNS Press).

Musabbikhin, A., Prasetyo, A. S., dan Satmoko, S. (2020). Hubungan Kohesivitas Dengan Partisipasi Anggota Pada Kelompok Tani Ternak Rejeki Lumintu Di Kelurahan Sumurejo Gunungpati Kota Semarang. JSEP: Jurnal Sosial ekonomi Pertanian, 13(3), 232-241.

https://doi.org/10.19184/jsep.v13i $\underline{3.18537}$

Prasetyo, A. S., Safitri, R., \& Hidayat, K. (2019). Strategi Komunikasi Ketua Dalam Meningkatkan Eksistensi Kelompok (Kasus di Kelompok Tani Sidodadi di Desa Junrejo, Kecamatan Junrejo Kota Batu Jawa Timur). Habitat, 30(1), 26-34. https://doi.org/10.21776/ub.habit at.2019.030.1.4 
Prasetyo, A. S., Sumekar, W., Kurniasari, D. A., \& Musabikin, A. 2020. Aktivitas dan Tingkat Partisipasi Anggota dalam Usahatani Ternak Sapi Perah di Kelompok Tani Ternak Rejeki Lumintu Gunungpati, Kota Semarang. Jurnal Agrinika: Jurnal Agroteknologi dan Agribisnis, $\quad 4(2), \quad 186$. https://doi.org/10.30737/agrinika. v4i 2.1053.

Sugiyono. (2007). Metode Penelitian Kuantitatid dan Kualitatif. Bandung: Alfabeta.

Sumekar, W., Prasetyo, A. S., \& Nadhila, F. I. (2021). Tingkat Kinerja Petugas Lapang Program Asuransi Usaha Ternak Sapi (AUTS) di Kecamatan Getasan. Jurnal Agrinika: Jurnal Agroteknologi dan Agribisnis, 5(1), 10-19.

https://doi.org/10.30737/agrinika. v5i1.1538.

Untarti, R., dan A, B, Kusuma. 2018. Meningkatkan partisipasi aktif mahasiswa melalui lesson study pada mata kuliah geometri ruang. J Pendidikan Matematika dan IImu Pengetahuan Alam. 9 (1): $15-30$.

Walgito, 1999. Psikologi Sosial (Suatu Pengantar). Yogyakarta: Andi.

Wawan, A., \& Dewi, M. 2010. Pengetahuan, Sikap, dan Perilaku Manusia. Yogyakarta: Nuha Medika. 